Historic, Archive Document

Do not assume content reflects current scientific knowledge, policies, or practices. 
RETURN POSTAGE GUARANTEED

T. R. SCHROEDER

Rare Cactus-Seeds \& Seedlings 4821 STRONG STREET CHICAGO, ILL.
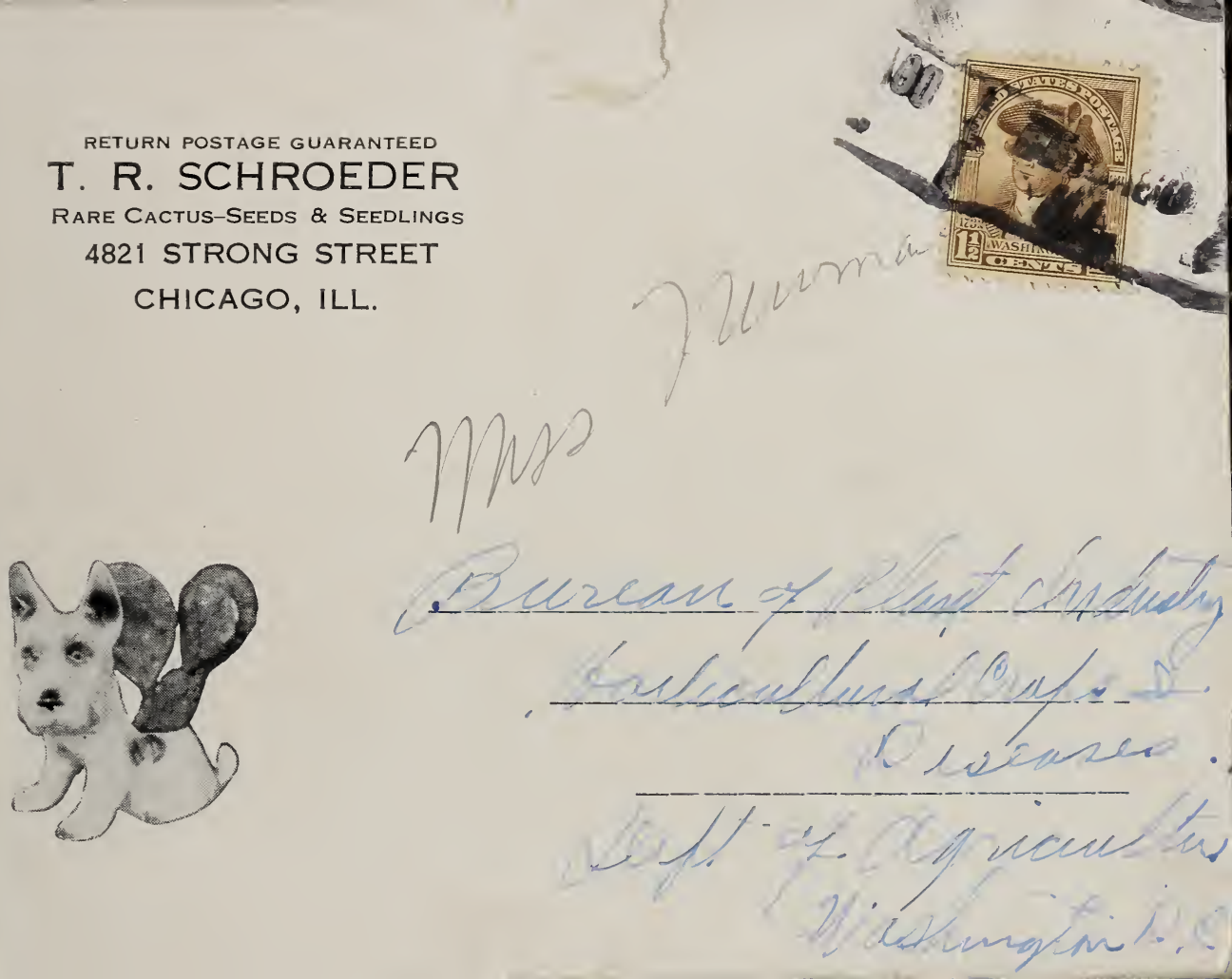



\section{LIST OF CACTI SEEDLINGS}

CEREUS

Silvestrix

Pachycereus pecten aborigineum

Cereus Giganteus (Carnegia)

Lophocereus Schottii

1 in.

Cereus peruvianus 1 in. $\$ 0.25$

2 in.

Cereus peruvianus 1 in.

2 in.

Grafting Cereus 6 in

6 in.

Harrissia Martinii

$1 \mathrm{ft}$.

Cephalocereus senilis (Old Man) per ft.

Cephalocereus Palmeri

Peniocereus Johonsonii

Five varieties of Cereus seedlings, our selection, including one Old Man cacti

Ten (10) varieties of Mammillaria seedlings, one year old, unnamed 15 each-all ten

\section{EUPHORBIAS}

Obesa 1 yr. $\$ 1.00$

2 yr.

bupleurifolia

$1 \mathrm{yr}$.

Mammilaris

1 in.

Ceriformis

Meloformis

Five varieties Euphorbias including one Obesa

Stepelia Variagata, 6 mo. seedlings

Echinocereus Engelmanii

Echinocereus Pectinata

Echinocereus Richenbachii

Echinocactus Ingens

Echinocactus Grussonii 1 yr. \$0 25

Echinocactus virodescens

Aloe Variagata

Aloe Striata

Aloe Humilis

Five different Aloes including one Variagata

Five varieties Haworthias, named

Five varieties Sempervivum, named, our selection

Five varieties Esheverias, named, our selection

Ten varieties hardy sedums, named, nice clumps 


\section{OPUNTIA SEEDLINCS, PLANTS AND ROOTED CUTTINCS}

Arborencens

$.1 \mathrm{yr}$. seedlings $\$ \mathbf{\$} 0.15$

trees $\$ 0.25$ up

Spineosa

$1 \mathrm{yr}$. seedlings

.15

Leptocalis

1 yr. seedlings

.10

$1 \mathrm{ft}$. trees .50 up

Santa Rita

Rooted Pad \$0.25

bush

.25 up

Basilaris

Rooted Pad

.25

Plants

$\$ 0.35$ up

Monocantha, plain

Rooted Pad

.20

Plants

.50 up

Monocantha Variagata

Rooted Pad

.25

Plants

.35 up

Microdasys

Rooted Pad

.25

Plants

.50 up

Plants

.50 up

(The two preceding varieties can be furnished first slab $25 \mathrm{c}$, all

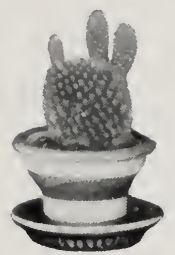

Opuntia

Microdasy additional pads growing on same plant 10 cents extra).

Cylindrica first inch $\$ 0.25$

Each additional inch

$\$ 0.25$

Refinesquiana (very hardy) 2 yr. plant

$\$ 0.25$

Vulgaris (hardy)

1 yr. plant

Suhulata

6 in.

Seven named varieties Opuntias, our selection

Astrophytum Asterias

2 in. dia. $\$ 1.50$

Astrophytum Myrośtigma

3 in. dia.

3.50

Lophora Williamsir, The Mescal Button, the Indian ceremonial plant

which contains a narcotic

Neomammilaria dioica seedling $\$ 0.15$

plant

Some beautiful clusters

Opuntia Ursina, long white hair-4 inch rooted cutting

Plants

Acanthocereus Pentagonus, three to six ribs

$\$ 0.25$ up

Cereus Gigantea 10 in. $\$ 2.50$

larger per ft. $\quad 5.00$

Ferocactus acanthodes (Mexican flame ball) .50 up

Ferocactus virodescens (the red-spines niggerhead of

California) .3 in. plant $\$ 0.50 \quad 5$ in.

Hamatacactus setispenus, large yellow flowers .75 up

Cereus harrissia Martinii (white flowers, night bloomer) .25 up $1 \mathrm{ft}$. \$0.50 large specimen plants

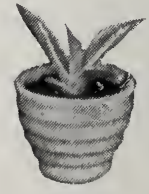

Agave Americana Marginata

Echinocereus fendleri-large lavender flowers-

Single specimen plants $\$ .35$ clusters

1.00

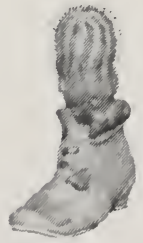

Echinocereus Pectinata

Echinocereus pectinata Rigidissima-the true rainbow

cactus from Arizona, well rooted plants

Fichincactus bi-color-purple flowers $\$ 9.15$

Echinocactus horizanthelonus .15

Echinocactus texensis (devil's head) 1.00

Echinocereus virdiflorus (green flowers)

Echinocereus dasyacantha (large yellow flowers)

Echinocereus pectinata $\$ 0.10 \quad \$ 0.50$ 
We are exclusive American agents for John Coutts Kendrew, S. Africa, for his rare Mesembrianthemum and aloe seeds. Dealers please ask for quantity discounts.

MESEMBRIANTHEMUM SEEDS-

Lithops bella
Lithops Lesliei _...25 seeds

(All prices postpaid)

\section{CACTI BOOKS THAT YOU SHOULD HAVE}

48 page booklet entitled Cacti in the Home

illustrated

$\$ 0.25$

Our Native Cacti by Ethel Baily Higgins

2.65

The Cactus Book by Dr. A. D. Houghton

2.40

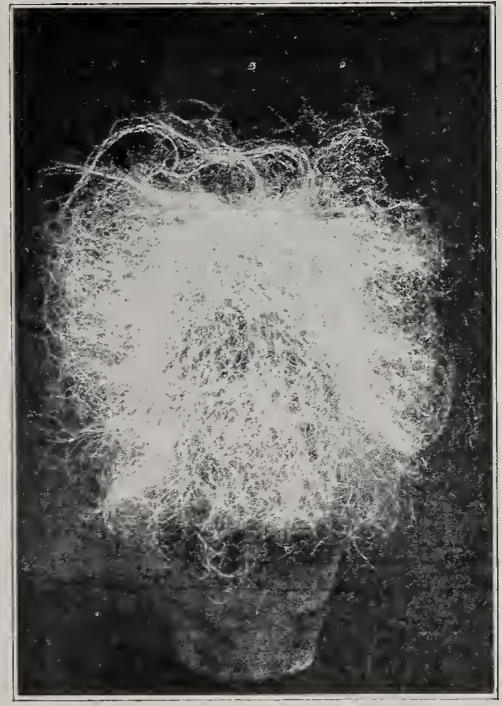

Cephalocereus Senilis

Join the Cactus and Succulent Society of America. Membership and subscription to magazine $\$ 3.00$ annually. We will be glad to send in your subscription.

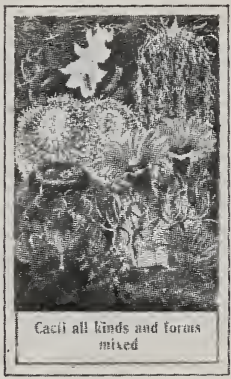

Seeds .. $\$ .10$ per pkt.

Another magazine on Cacti, very excellent and not too technical for the amateur is The Desert Magazine, published in Pasadena, California, at $\$ 1.50$ per annum.

We will be glad to take your subscriptions with your plant and seed orders.

All orders of $\$ 1.00$ or over will be sent post paid. For smaller amounts add 15 cents to cover packing. All seeds are sent post paid any quantity.

\section{IMPORTANT}

Due to the closing of all banks in our vicinity it is impossible to accept checks. For amounts of 75 cents or less please send stamps. Amounts over 75 cents Postal Money Orders only. Thank you. 
